\title{
28 Resarch Soure \\ On the in situ elimination of pores during laser powder bed fusion of a titanium alloy
}

\section{Research Article}

Keywords:

Posted Date: September 3rd, 2021

DOI: https://doi.org/10.21203/rs.3.rs-386269/v2

License: (c) (i) This work is licensed under a Creative Commons Attribution 4.0 International License.

Read Full License 


\section{Abstract}

The full text of this preprint has been withdrawn by the authors while they make corrections to the work. Therefore, the authors do not wish this work to be cited as a reference. Questions should be directed to the corresponding author.

\section{Full Text}

The authors have withdrawn this preprint from Research Square. 